3 Koolen DA, Sharp AJ, Hurst JA et al: Clinical and molecular delineation of the 17q21.31 microdeletion syndrome. J Med Genet 2008; 45: 710-720.

4 Ben-Shachar S, Ou Z, Shaw CA et al: 22q11.2 distal deletion: a recurrent genomic disorder distinct from DiGeorge syndrome and velocardiofacial syndrome. Am J Hum Genet 2008; 82: 214-221.

5 Ballif BC, Hornor SA, Jenkins E et al: Discovery of a previously unrecognized microdeletion syndrome of 16p11.2-p12.2. Nat Genet 2007; 39: 1071-1073.

6 Ballif BC, Theisen A, Coppinger J et al: Expanding the clinical phenotype of the 3q29 microdeletion syndrome and characterization of the reciprocal microduplication. Mol Cytogenet 2008; 1 : 8.

7 Sharp AJ, Selzer RR, Veltman JA et al: Characterization of a recurrent 15q24 microdeletion syndrome. Hum Mol Genet 2007; 16: 567-572.

8 Ullmann R, Turner G, Kirchhoff M et al: Array CGH identifies reciprocal 16p13.1 duplications and deletions that predispose to autism and/or mental retardation. Hum Mutat 2007; 28: 674-682.

9 Kleefstra T, Brunner HG, Amiel J et al: Loss-of-function mutations in euchromatin histone methyl transferase 1 (EHMT1) cause the 9q34 subtelomeric deletion syndrome. Am J Hum Genet 2006; 79: 370-377.

10 Petrij F, Giles RH, Dauwerse HG et al: Rubinstein-Taybi syndrome caused by mutations in the transcriptional co-activator CBP. Nature 1995; 376: 348-351.

11 Breuning MH, Dauwerse HG, Fugazza G et al: Rubinstein-Taybi syndrome caused by submicroscopic deletions within 16p13.3. Am J Hum Genet 1993; 52: 249-254.

12 Vissers LE, de Vries BB, Osoegawa $\mathrm{K}$ et al: Array-based comparative genomic hybridization for the genomewide detection of submicroscopic chromosomal abnormalities. Am J Hum Genet 2003; 73: 1261-1270.

13 Koolen DA, Vissers LE, Nillesen W et al: A novel microdeletion, del(2)(q22.3q23.3) in a mentally retarded patient, detected by array-based comparative genomic hybridization. Clin Genet 2004; 65: 429-432.

14 Jaillard S, Dubourg C, Gérard-Blanluet M et al: 2q23.1 microdeletion identified by array-CGH: an emerging phenotype with Angelman-like features? J Med Genet 2008 (epub ahead of print).
15 Wagenstaller J, Spranger S, Lorenz-Depiereux B et al: Copy-number variations measured by single-nucleotide-polymorphism oligonucleotide arrays in patients with mental retardation. Am J Hum Genet 2007; 81: 768-779.

16 De Gregori M, Ciccone R, Magini $\mathrm{P}$ et al: Cryptic deletions are a common finding in 'balanced' reciprocal and complex chromosome rearrangements: a study of 59 patients. J Med Genet 2007; 44: 750-762.

17 de Vries BB, Pfundt R, Leisink $M$ et al: Diagnostic genome profiling in mental retardation. Am J Hum Genet 2005; 77: 606-616.

18 Schouten JP, McElgunn CJ, Waaijer R, Zwijnenburg D, Diepvens F, Pals G: Relative quantification of 40 nucleic acid sequences by multiplex ligation-dependent probe amplification. Nucleic Acids Res 2002; 30: e57.

19 Rozen S, Skaletsky H: Primer3 on the WWW for general users and for biologist programmers. Methods Mol Biol 2000; 132: 365-386.

20 Marcelis CL, Hol FA, Graham GE et al: Genotype-phenotype correlations in MYCNrelated Feingold syndrome. Hum Mutat 2008; 29: 1125-1132.

21 Livak KJ, Schmittgen TD: Analysis of relative gene expression data using real-time quantitative PCR and the 2(-Delta Delta C(T)) Method. Methods 2001; 25: 402-408.

22 Clayton-Smith J, Laan L: Angelman syndrome: a review of the clinical and genetic aspects. J Med Genet 2003; 40: 87-95.

23 Gropman AL, Duncan WC, Smith AC: Neurologic and developmental features of the Smith-Magenis syndrome (del 17p11.2). Pediatr Neurol 2006; 34: 337-350.

24 Roloff TC, Ropers HH, Nuber UA: Comparative study of methyl-CpG-binding domain proteins. BMC Genomics 2003; 4: 1.

25 Doyon Y, Selleck W, Lane WS, Tan S, Cote J: Structural and functional conservation of the NuA4 histone acetyltransferase complex from yeast to humans. Mol Cell Biol 2004; 24: 1884-1896.

26 Perry J: The Epc-N domain: a predicted protein-protein interaction domain found in select chromatin associated proteins. BMC Genomics 2006; 7: 6 .

27 Kramer JM, van $\mathrm{BH}$ : Genetic and epigenetic defects in mental retardation. Int J Biochem Cell Biol 2009; 41: 96-107.

\title{
Corrigendum to: The 2q23.1 microdeletion syndrome: clinical and behavioural phenotype
}

\author{
Bregje WM van Bon, David A Koolen, Louise Brueton, Dominic McMullan, Klaske D Lichtenbelt, \\ Lesley C Adès, Gregory Peters, Kate Gibson, Francesca Novara, Tiziano Pramparo, Bernardo Dalla Bernardina, \\ Leonardo Zoccante, Umberto Balottin, Fausta Piazza, Vanna Pecile, Paolo Gasparini, Veronica Guerci, \\ Marleen Kets, Rolph Pfundt, Arjan P de Brouwer, Joris A Veltman, Nicole de Leeuw, Meredith Wilson, \\ Jayne Antony, Santina Reitano, Daniela Luciano, Marco Fichera, Corrado Romano, Han G Brunner, \\ Orsetta Zuffardi and Bert BA de Vries
}

European Journal of Human Genetics (2010) 18, 170; doi:10.1038/ejhg.2009.200

Correction to: European Journal of Human Genetics advance online publication 7 October 2009; doi: 10.1038/ejhg.2009.152

Since the publication of the above paper, the authors noticed a co-author was missing from the authors' list: Dr Susan Moloney, and her affiliation is MBBS FRACP, Department of Paediatrics, Gold Coast Health Service District, Southport, Gold Coast, Queensland, Australia. The complete authors' list is reproduced below:

Bregje WM van Bon, David A Koolen, Louise Brueton, Dominic McMullan, Klaske D Lichtenbelt, Lesley C Adès, Gregory Peters,
Kate Gibson, Susan Moloney, Francesca Novara, Tiziano Pramparo, Bernardo Dalla Bernardina, Leonardo Zoccante, Umberto Balottin, Fausta Piazza, Vanna Pecile, Paolo Gasparini, Veronica Guerci, Marleen Kets, Rolph Pfundt, Arjan P de Brouwer, Joris A Veltman, Nicole de Leeuw, Meredith Wilson, Jayne Antony, Santina Reitano, Daniela Luciano, Marco Fichera, Corrado Romano, Han G Brunner, Orsetta Zuffardi and Bert BA de Vries

The authors would like to apologise for this mistake. 